\title{
Immunomodulation of Skin Cytokine Secretion by House Dust Mite Extracts
}

\author{
Larry G. Arlian Marjorie S. Morgan \\ Department of Biological Sciences, Wright State University, Dayton, Ohio, USA
}

\section{Key Words}

Immunomodulation · House dust mite $\cdot$ Human skin

equivalent $\cdot$ Cytokines $\cdot$ Chemokines

\begin{abstract}
Background: Skin contact with house dust mites may contribute to atopic dermatitis and other skin diseases. We sought to determine if molecules from house dust mites could influence the release of proinflammatory cytokines and chemokines from epidermal keratinocytes and dermal fibroblasts grown in a human skin equivalent (HSE) model. Methods: HSEs consisting of an epidermis of keratinocytes with stratum corneum over a dermis of fibroblasts in a collagen matrix were challenged with Dermatophagoides farinae, D. pteronyssinus and Euroglyphus maynei mite extracts. Results: HSEs secreted interleukin (IL)-1 $\alpha$, IL-1 receptor antagonist, IL-6, IL-8, cutaneous T cell-attracting chemokine, transforming growth factor- $\alpha$, granulocyte/macrophage and macrophage colony-stimulating factors and vascular endothelial cell growth factor in response to at least 1 mite extract. Extracts of different mite species stimulated HSEs to release different cytokines. Therefore, extracts of different species contained different molecules or different concentrations of similar molecules. The cytokine release profiles of cells in the HSEs were not the same as for monocultured keratinocytes and fibroblasts. Conclusions: Molecules
\end{abstract}

from house dust mites are capable of inducing the release of multiple proinflammatory cytokines and chemokines from epidermal keratinocytes and dermal fibroblasts. Avoiding skin contact with house dust mites would reduce the possibility of mite-induced inflammation in the skin. Therefore, measures to reduce contact with mite molecules such as frequent vacuuming of upholstered furniture and carpets and laundering of clothing and bedding to remove mite molecules and allergens could reduce skin contact with mite molecules and diminish exacerbations of skin inflammation in patients with atopic dermatitis and other skin diseases.

Copyright $\odot 2011$ S. Karger AG, Basel

\section{Introduction}

The house dust mites Dermatophagoides farinae, $D$. pteronyssinus and Euroglyphus maynei are ubiquitous inhabitants of homes worldwide and are particularly prevalent in homes in humid geographical areas. Within homes they are most abundant in high-use areas where skin scales accumulate and serve as their food. This includes carpets, upholstered furniture such as couches, recliners and chairs, and mattresses and bedding. Human skin may come into contact with dust mites when a person uses furniture and beds or engages in activities on car-

\section{KARGER}

(C) 2011 S. Karger AG, Basel

Fax +41613061234

E-Mail karger@karger.ch

www.karger.com
Accessible online at:

www.karger.com/iaa
Correspondence to: Dr. Larry G. Arlian

Department of Biological Sciences, Wright State University

3640 Colonel Glenn Highway

Dayton, OH 45435 (USA)

Tel. +1 937775 2568, Fax +1 937775 3320, E-Mail larry.arlian@wright.edu 
pets. There are reports of house dust mites being recovered from human skin and clothing [1-4].

A defective skin barrier may allow penetration of mite molecules into the lower epidermis and dermis [5-10]. Molecules in mite material include both allergens and nonallergens, and some of these are enzymes. House dust mite group 1 allergens are cysteine proteases, and groups 3, 6 and 9 are serine proteases [11]. Protease enzymes from house dust mites, solvents, volatile organics, soaps, detergents, surfactants and abrasive materials can damage the skin epidermal surface barrier, and this can allow penetration of mite molecules into the lower epidermis and dermis $[6,12]$. The recombinant allergen Der $f 1$ is a cysteine protease that has been shown to reduce the barrier function of skin in nude mice [13]. Positive patch test reactions to house dust mites have been reported [14-16]. Serine peptidases from fecal pellets of $D$. pteronyssinus cleave occludin of epithelial tight junctions of cultured airway epithelial cells $[17,18]$. Likewise, $D$. farinae and $D$. pteronyssinus extracts cause changes in growth and reduced adhesion in cA549 type II epithelial cells [19].

This chemical and physical disruption may allow penetration of molecules that may induce epidermal and dermal inflammation and immune responses that are mediated by cytokines and chemokines from stimulated keratinocytes, fibroblasts, microvascular endothelial cells and infiltrating cells, including Langerhans cells, lymphocytes and monocytes/macrophages, neutrophils and eosinophils. Stimulated keratinocytes and fibroblasts produce and secrete multiple cytokines that promote $\mathrm{cu}^{-}$ taneous inflammation. Previous research has shown that house dust mite and stored product mite extracts stimulate the secretion of cytokines from cultured human dermal keratinocytes, fibroblasts and microvascular endothelial cells $[20,21]$. Both $D$. farinae and $D$. pteronyssinus extracts stimulate cultured keratinocytes to increase secretion of the chemokine growth-related oncogene- $\alpha$ (GRO $\alpha, C X C L 1)$, which is chemotactic for the extravasation of leukocytes during inflammation [20]. Likewise, D. farinae and/or D. pteronyssinus extracts induce cultured normal human dermal fibroblasts to secrete interleukin (IL)-6, IL-8 (CXCL8), monocyte chemoattractant protein-1 (MCP-1, CCL2) and macrophage colony-stimulating factor (M-CSF) [20]. Kato et al. [22] demonstrated that whole-mite culture extract and recombinant Der $\mathrm{f} 1$ and Der $\mathrm{p} 1$ induced the release of IL- 8 and granulocyte/ macrophage colony-stimulating factor (GM-CSF) from cultured primary human keratinocytes from infant foreskins and from the human keratinocyte cell line HaCaT. In these previous studies, the effect of mite extracts was investigated using monocultures of epidermal keratinocytes or dermal fibroblasts. In vivo in the skin, fibroblasts and keratinocytes may respond differently to mite extracts because the cytokines secreted by one cell type can influence the function of the others and of the fibroblasts that are associated with a collagen matrix $[12,23]$. The cytokines that these 2 cell types produce can mediate the function of many other cells in the skin, including microvascular endothelial cells, which are key to the regulation of extravasation of inflammatory and immune cells. Therefore, the responses of keratinocytes and fibroblasts are important in the progression of inflammatory and immune responses and the manifestation of atopic dermatitis. Here, we report the effect of house dust mite extracts on fibroblasts and keratinocytes together in human skin equivalents (HSEs). The HSE is structurally similar to normal skin. It consists of an epidermis with a stratum corneum over living keratinocytes and a basal layer grown over a dermis consisting of fibroblasts in a collagen matrix $[23,24]$.

\section{Methods}

Mite Extracts

The house dust mites D. farinae, D. pteronyssinus and E. maynei were cultured in our laboratory at $75 \%$ relative humidity and room temperature. Mites were collected as they migrated from thriving cultures and were frozen until use. Soluble protein extracts were prepared by extracting a weighed amount of mites in endotoxin-free water (Lonza, Walkersville, Md., USA) for $24 \mathrm{~h}$ at $4^{\circ} \mathrm{C}$. Samples were sonicated for $15 \mathrm{~min}$ on ice then ground in a TenBroeck homogenizer, and insoluble material was removed by centrifugation. The supernatant (extract) was collected and sterile-filtered into sterile vials. Protein content was measured using the Bradford protein assay with bovine serum albumin as the standard [25]. Endotoxin content was determined using a Limulus Amebocyte Lysate QCL-1000 assay kit from Lonza according to the directions provided.

\section{HSE Challenge}

EpiDerm EFT-400 full-thickness HSEs and medium were purchased from MatTek Corp. (Ashland, Mass., USA). Upon arrival, HSEs on their supports were transferred to new 6-well culture plates containing $3.0 \mathrm{ml}$ of fresh medium per well, and plates were placed in a $37^{\circ} \mathrm{C}$ incubator with $5-7 \% \mathrm{CO}_{2}$. The next day, HSEs were transferred to new plates containing $5.0 \mathrm{ml}$ of fresh medium. The epidermal surfaces of HSEs were inoculated with $100 \mu \mathrm{g}$ of mite extract protein $(26-38 \mu \mathrm{l})$, while the surfaces of control HSEs were not inoculated. There were 3 replicate HSEs for each test condition. At 6, 12, 18 and $24 \mathrm{~h}$ after inoculation, each HSE on its support was lifted from the well, the medium was mixed and a $550-\mu \mathrm{l}$ aliquot was removed from the sample well and frozen at $-80^{\circ} \mathrm{C}$. At the conclusion of the experiment (after $48 \mathrm{~h}$ ), the remaining medium was collected and frozen. 
Table 1. Immunomodulation activities of house dust mite extracts on normal human skin keratinocytes and fibroblasts in monocultures $(24 \mathrm{~h})$ and HSEs $(48 \mathrm{~h})$

\begin{tabular}{|c|c|c|c|c|c|c|c|c|c|c|}
\hline & \multirow[b]{2}{*}{$\begin{array}{l}\text { Cell type: } \\
\text { Inoculum: }\end{array}$} & \multicolumn{3}{|c|}{ D. farinae extract } & \multicolumn{3}{|c|}{ D. pteronyssinus extract } & \multicolumn{3}{|c|}{ E. maynei extract } \\
\hline & & $\begin{array}{l}\text { keratinocytes } \\
100 \mu \mathrm{g} / \mathrm{ml} \\
\text { (in media) }\end{array}$ & $\begin{array}{l}\text { fibroblasts } \\
100 \mu \mathrm{g} / \mathrm{ml} \\
\text { (in media) }\end{array}$ & $\begin{array}{l}\text { HSEs } \\
100 \mu \mathrm{g} \\
\text { (on surface) }\end{array}$ & $\begin{array}{l}\text { keratinocytes } \\
100 \mu \mathrm{g} / \mathrm{ml} \\
\text { (in media) }\end{array}$ & $\begin{array}{l}\text { fibroblasts } \\
100 \mu \mathrm{g} / \mathrm{ml} \\
\text { (in media) }\end{array}$ & $\begin{array}{l}\text { HSEs } \\
100 \mu g \\
\text { (on surface) }\end{array}$ & $\begin{array}{l}\text { keratinocytes } \\
100 \mu \mathrm{g} / \mathrm{ml} \\
\text { (in media) }\end{array}$ & $\begin{array}{l}\text { fibroblasts } \\
100 \mu \mathrm{g} / \mathrm{ml} \\
\text { (in media) }\end{array}$ & $\begin{array}{l}\text { HSEs } \\
100 \mu \mathrm{g} \\
\text { (on surface) }\end{array}$ \\
\hline CTACK & & $\mathrm{X}$ & $\mathrm{X}$ & $>$ & $\mathrm{X}$ & $\mathrm{X}$ & $>$ & $\mathrm{X}$ & $\mathrm{X}$ & $=$ \\
\hline TSLP & & $\mathrm{X}$ & $\mathrm{X}$ & $=$ & $\mathrm{X}$ & $\mathrm{X}$ & $=$ & $\mathrm{X}$ & $\mathrm{X}$ & $=$ \\
\hline $\mathrm{GRO} \alpha$ & & $={ }^{\mathrm{a}}$ & $\mathrm{X}$ & $=$ & $={ }^{\mathrm{a}}$ & $\mathrm{X}$ & $=$ & $<<^{\mathrm{a}}$ & $\mathrm{X}$ & $=$ \\
\hline TGF $\alpha$ & & $={ }^{\mathrm{a}}$ & $\mathrm{X}$ & $>$ & $={ }^{\mathrm{a}}$ & $\mathrm{X}$ & $>$ & $<\mathrm{a}$ & $\mathrm{X}$ & $>$ \\
\hline IL- $1 \alpha$ & & $\mathrm{X}$ & $0^{\mathrm{a}}$ & $=$ & $\mathrm{X}$ & $0^{\mathrm{a}}$ & $>$ & $\mathrm{X}$ & $0^{\mathrm{a}}$ & $>$ \\
\hline IL-1 $\beta$ & & $0^{\mathrm{a}}$ & $0^{\mathrm{a}}$ & $\mathrm{X}$ & $0^{\mathrm{a}}$ & $0^{\mathrm{a}}$ & $\mathrm{X}$ & $0^{\mathrm{a}}$ & $0^{\mathrm{a}}$ & $\mathrm{X}$ \\
\hline IL-1ra & & $={ }^{\mathrm{a}}$ & $0^{\mathrm{a}}$ & $=$ & $={ }^{\mathrm{a}}$ & $0^{\mathrm{a}}$ & $>$ & $={ }^{\mathrm{a}}$ & $0^{\mathrm{a}}$ & $=$ \\
\hline IL-3 & & $0^{\mathrm{a}}$ & $\mathrm{X}$ & $\mathrm{X}$ & $0^{\mathrm{a}}$ & $\mathrm{X}$ & $\mathrm{X}$ & $0^{\mathrm{a}}$ & $\mathrm{X}$ & $\mathrm{X}$ \\
\hline IL-6 & & $0^{\mathrm{a}}$ & $>^{\mathrm{a}}$ & $>$ & $0^{\mathrm{a}}$ & $={ }^{\mathrm{a}}$ & $>$ & $0^{\mathrm{a}}$ & $={ }^{\mathrm{a}}$ & $=$ \\
\hline IL-7 & & $0^{\mathrm{a}}$ & $0^{\mathrm{a}}$ & $\mathrm{X}$ & $0^{\mathrm{a}}$ & $0^{\mathrm{a}}$ & $\mathrm{X}$ & $0^{\mathrm{a}}$ & $0^{\mathrm{a}}$ & $\mathrm{X}$ \\
\hline IL-8 & & $>b$ & $>^{a}$ & $=$ & $>b$ & $>^{\mathrm{a}}$ & $>$ & $>b$ & $>^{\mathrm{a}}$ & $>$ \\
\hline IL-10 & & $0^{\mathrm{a}}$ & $\mathrm{X}$ & $\mathrm{X}$ & $0^{\mathrm{a}}$ & $\mathrm{X}$ & $\mathrm{X}$ & $0^{\mathrm{a}}$ & $\mathrm{X}$ & $\mathrm{X}$ \\
\hline IL-12p7 & & $0^{\mathrm{a}}$ & $\mathrm{X}$ & $\mathrm{X}$ & $0^{\mathrm{a}}$ & $\mathrm{X}$ & $\mathrm{X}$ & $0^{\mathrm{a}}$ & $\mathrm{X}$ & $\mathrm{X}$ \\
\hline IL-15 & & $0^{\mathrm{a}}$ & $0^{\mathrm{a}}$ & $\mathrm{X}$ & $0^{\mathrm{a}}$ & $0^{\mathrm{a}}$ & $\mathrm{X}$ & $0^{\mathrm{a}}$ & $0^{\mathrm{a}}$ & $\mathrm{X}$ \\
\hline MCP-1 & & $0^{\mathrm{a}}$ & $>^{\mathrm{a}}$ & $=$ & $0^{\mathrm{a}}$ & $={ }^{\mathrm{a}}$ & $=$ & $0^{\mathrm{a}}$ & $={ }^{\mathrm{a}}$ & $=$ \\
\hline G-CSF & & $\mathrm{X}$ & $0^{\mathrm{a}}$ & $=$ & $\mathrm{X}$ & $0^{\mathrm{a}}$ & $=$ & $\mathrm{X}$ & $0^{\mathrm{a}}$ & $=$ \\
\hline GM-CSF & & $0^{\mathrm{a}}$ & $0^{\mathrm{a}}$ & $=$ & $0^{\mathrm{a}}$ & $0^{\mathrm{a}}$ & $>$ & $0^{\mathrm{a}}$ & $0^{\mathrm{a}}$ & $>$ \\
\hline M-CSF & & $\mathrm{X}$ & $>^{a}$ & $=$ & $\mathrm{X}$ & $>^{a}$ & $>$ & $\mathrm{X}$ & $={ }^{\mathrm{a}}$ & $>$ \\
\hline VEGF & & $\mathrm{X}$ & $0^{\mathrm{b}}$ & $>$ & $\mathrm{X}$ & $0^{\mathrm{b}}$ & $=$ & $\mathrm{X}$ & $0^{\mathrm{b}}$ & $=$ \\
\hline Eotaxin & & $\mathrm{X}$ & $0^{\mathrm{a}}$ & $\mathrm{X}$ & $\mathrm{X}$ & $0^{\mathrm{a}}$ & $\mathrm{X}$ & $\mathrm{X}$ & $0^{\mathrm{a}}$ & $\mathrm{X}$ \\
\hline SCF & & $\mathrm{X}$ & $0^{\mathrm{a}}$ & $\mathrm{X}$ & $\mathrm{X}$ & $0^{\mathrm{a}}$ & $\mathrm{X}$ & $\mathrm{X}$ & $0^{\mathrm{a}}$ & $\mathrm{X}$ \\
\hline $\mathrm{TNF} \alpha$ & & $\mathrm{X}$ & $0^{\mathrm{a}}$ & $\mathrm{X}$ & $\mathrm{X}$ & $0^{\mathrm{a}}$ & $\mathrm{X}$ & $\mathrm{X}$ & $0^{\mathrm{a}}$ & $\mathrm{X}$ \\
\hline
\end{tabular}

Data are compared to paired constitutive controls and are scored as equivalent to $(=)$, downmodulated $(<)$ or upmodulated $(>)$. Some cytokines were not detected $(0)$ while others were not measured (X). Keratinocytes and fibroblasts were monocultures. Collection sites were media in wells for all extracts. HSE data are from this study at $48 \mathrm{~h}$. SCF $=$ Stem cell factor; TNF $\alpha=$ tumor necrosis factor- $\alpha$.

a Data from Arlian et al. [20].

b Data from Arlian et al. [unpubl.].

Cytokine Measurements

The concentrations of various cytokines in the culture medium aliquots were measured using ELISA kits from R\&D Systems (Minneapolis, Minn., USA). The cytokines selected for assay in this study were those that we had previously detected in supernatants of monocultures of keratinocytes or fibroblasts challenged with dust mite extracts (table 1) [20]. Data are presented as means \pm SEM. Statistical significance was determined using a singlefactor analysis of variance of differences compared to controls, with $\mathrm{p}<0.05$ judged as significant.

\section{Results}

\section{Endotoxin and Protein Concentrations of Extracts}

The endotoxin concentrations of the mite extracts were $4.57 \times 10^{6}, 1.15 \times 10^{6}$ and $10.2 \times 10^{6}$ endotoxin units $(\mathrm{EU}) / \mathrm{ml}$ for $D$. farinae, D. pteronyssinus and E. may- $n e i$, respectively. The endotoxin concentration of $D$. farinae extract was 4.0 times greater than that of $D$. pteronyssinus. The endotoxin concentration of E. maynei was 2.2 and 8.9 times greater than that of $D$. farinae and D. pteronyssinus, respectively.

Protein concentrations in the extracts of $D$. farinae, $D$. pteronyssinus and E. maynei were 3.07, 3.81 and $2.64 \mathrm{mg} /$ $\mathrm{ml}$, respectively. Therefore, HSEs inoculated with $100 \mu \mathrm{g}$ of extract protein were also inoculated with 149,000 EU from $D$. farinae, $30,100 \mathrm{EU}$ from $D$. pteronyssinus or 386,000 EU from E. maynei.

\section{Control HSEs}

Uninoculated HSEs constitutively secreted cutaneous T cell-attracting chemokine (CTACK, CCL27), GRO $\alpha$, IL-6, IL-8, MCP-1, granulocyte colony-stimulating factor 
(G-CSF), GM-CSF, M-CSF and vascular endothelial cell growth factor (VEGF), and the levels of these cytokines in the media beneath these control samples increased during the 48-hour experimental period (fig. 1). Conversely, no thymic stromal lymphopoietin (TSLP), transforming growth factor- $\alpha$ (TGF $\alpha$ ) or IL-1 $\alpha$ was detected in media from control HSEs at any time during the experiment. IL-1 receptor antagonist (IL-1ra) was present in the medium used to culture the HSEs, and its level dropped in medium collected from the uninoculated HSEs over the course of the experiment.

\section{Inoculated HSEs}

TGF $\alpha$. D. farinae, D. pteronyssinus and E. maynei extracts induced the secretion of small but significant amounts of TGF $\alpha$ (fig. 1). This was the only cytokine significantly upregulated by extracts of all 3 mite species.

$I L-6$ and $I L-8$. HSEs constitutively secreted copious amounts of both IL-6 and IL-8. D. pteronyssinus extract significantly increased the secretion of these cytokines above control levels (fig. 1). D. farinae extract induced significantly increased secretion of IL-6 but not of IL-8. Conversely, E. maynei extract induced significantly increased secretion of IL- 8 but not IL- 6 .

Colony-Stimulating Factors. Extracts of D. pteronyssinus and E. maynei upregulated production of GM-CSF and M-CSF (fig. 1). D. farinae extract did not induce significant secretion of either of these factors. No dust mite extract significantly upregulated G-CSF levels.

$V E G F$. Secretion of VEGF was enhanced by stimulation with extracts of $D$. farinae but not by extracts of $D$. pteronyssinus or E. maynei (fig. 1).

$I L-1 \alpha$ and IL-1ra. IL-1 $\alpha$ was not constitutively secreted by uninoculated HSEs, but extracts of $D$. pteronyssinus and E. maynei induced significant production of some IL-1 $\alpha$ (fig. 1). The medium used to culture the HSEs had considerable amounts of IL-1ra, but compared to control HSEs, only those challenged with $D$. pteronyssinus extract had significantly elevated levels of this substance at the end of the experiment.

CTACK. Extracts of the Dermatophagoides mites significantly upregulated CTACK production above control levels (fig. 1).

TSLP, GRO $\alpha$ and MCP-1. TSLP was not constitutively produced by HSEs, and only trace amounts of it were detected in response to stimulation with any mite extract. GRO $\alpha$ and MCP-1 levels increased over time in the medium beneath all HSEs, but none of the mite extracts induced secretion levels that were significantly different from those of control tissues (constitutive secretion; fig. 1).

\section{Discussion}

Secretion of cytokines and chemokines by epidermal keratinocytes and dermal fibroblasts can play a major role in the pathogenesis of the skin, including atopic dermatitis. A double-blind controlled trial has shown that effective house dust mite avoidance measures greatly reduce the activity of atopic dermatitis [26]. Previously, we found that molecules in house dust mite extracts could modulate the secretion of proinflammatory cytokines and chemokines secreted by cultured normal keratinocytes and fibroblasts [20] (table 1). Specifically, keratinocytes stimulated with E. maynei extract downregulated the constitutive secretion of TGF $\alpha$ and GRO $\alpha$ [20]. Cultured fibroblasts stimulated with $D$. farinae increased secretion of IL-6, IL-8, MCP-1 and M-CSF [20]. In contrast, cultured fibroblasts stimulated with $D$. pteronyssinus increased secretion of IL- 8 and M-CSF but not of IL- 6 or MCP-1, while E. maynei extract only stimulated increased IL-8 secretion. In this previous study, the cells stimulated with mite extract were monocultures of either keratinocytes or fibroblasts. Thus, those cells responded independently of other stimuli such as cytokines, chemokines and physical contact with other cell types that are present in vivo in their natural environment. Therefore, in the present study, we stimulated HSEs that contained both keratinocytes and fibroblasts in a collagen matrix to see if cell and matrix interactions as they occur in vivo would result in similar responses.

A significant finding in the current study was that the responses of keratinocytes and fibroblasts together in the HSE model in some cases were different from those of the isolated cultured cells. Cells in HSEs (fibroblasts and keratinocytes together) secreted IL-1ra, TGF $\alpha$ and GMCSF in response to extract of at least 1 mite species, but fibroblasts and/or keratinocytes in monoculture did not (table 1). GM-CSF was undetectable in monocultures, but significant levels were secreted by HSEs. Keratinocyte monocultures did not secrete MCP-1 constitutively or when stimulated with any mite extract, while fibroblast monocultures secreted only small amounts $(<200 \mathrm{pg} /$ $\mathrm{ml}$ ). However, when keratinocytes and fibroblasts were cocultured in the HSE format, substantial amounts of MCP-1 were secreted. HSEs secreted IL-6, IL-8 and MCSF at levels similar to monocultured fibroblasts. Cultured keratinocytes, like HSEs, secreted IL-8. Clearly, the cell response was modified by the interaction of cells and matrix in the HSE. It is interesting that HSEs, keratinocytes and fibroblasts all secreted IL- 8 in response to extracts of all 3 species of house dust mite. IL- 8 is a chemo- 


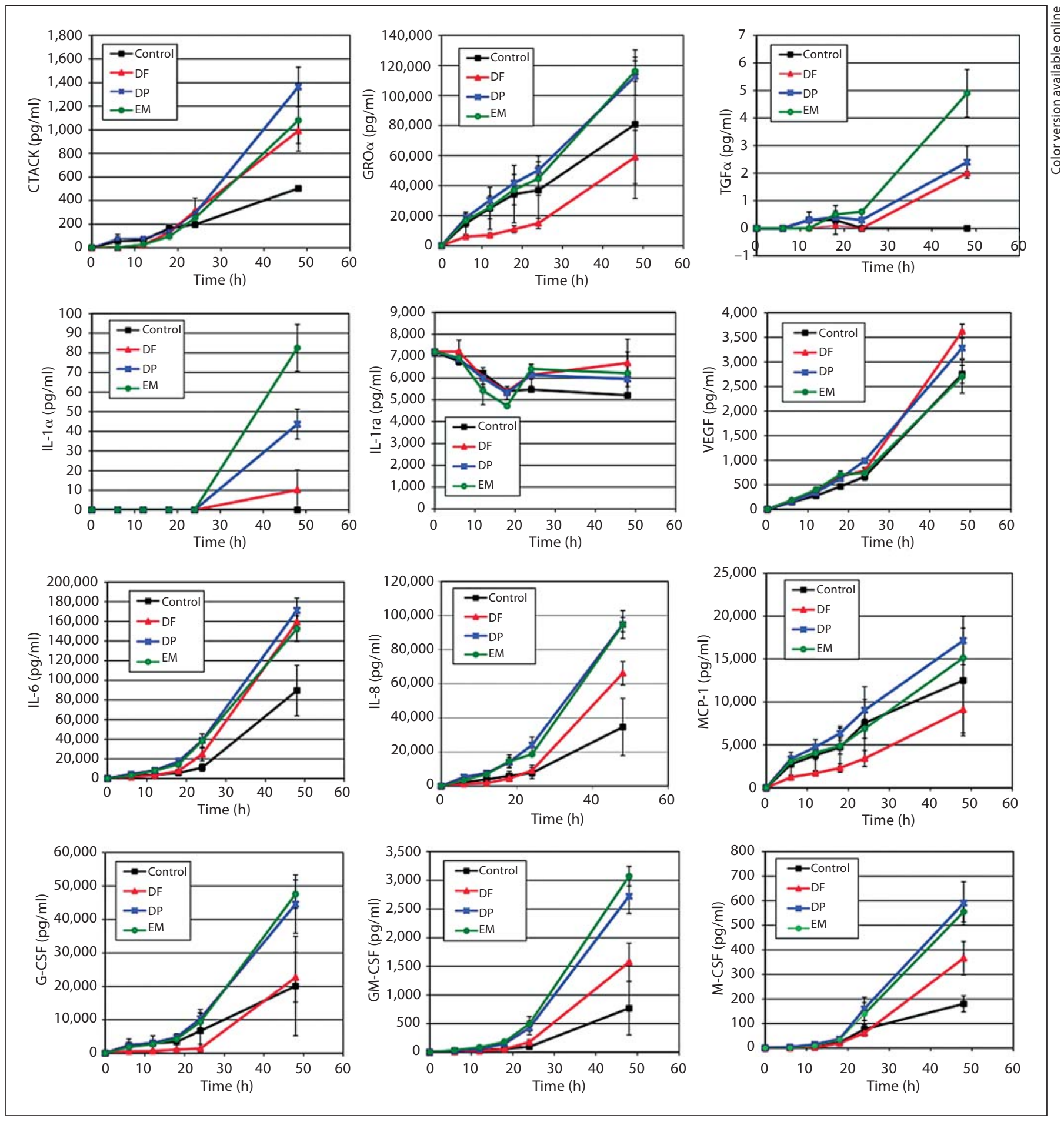

Fig. 1. Time course of cytokine secretion by HSEs in response to surface inoculation with $100 \mu \mathrm{g}$ of house dust mite extract protein from D. farinae (DF), D. pteronyssinus (DP) or E. maynei (EM). 
kine that is chemotactic for neutrophils and promotes their extravasation from the bloodstream into the dermis.

Consistent with our previous findings using monocultures of cells, another important finding of this research was that the extracts made from different mite species could induce different responses. Both $D$. farinae and $D$. pteronyssinus extracts stimulated significant IL- 6 and CTACK secretion by HSEs but E. maynei did not. D. pteronyssinus and E. maynei significantly stimulated IL- $1 \alpha$, IL-8, M-CSF and GM-CSF secretion but $D$. farinae did not. D. farinae stimulated secretion of VEGF but neither D. pteronyssinus nor E. maynei did. It is not clear what mechanism underlies these differential responses. It is likely that the extracts from the 3 different mite species contain different molecules or different quantities of similar molecules. If different molecules are present in the extract, these different molecules may stimulate the cells via different receptors and mechanisms (pathways). Also, our results and those of previous studies show that the extracts of the different species contain different concentrations of endotoxins [27]. This may influence signaling via the toll-like receptor-4 pathway and others. However, the hierarchy of endotoxin concentrations was E. maynei $>D$. farinae $>D$. pteronyssinus, while the hierarchy of overall cytokine responses was $D$. pteronyssinus $>E$. maynei $>D$. farinae. This suggests that the responses were not induced primarily by endotoxin in the extracts. Likewise, mite extracts contain protease enzymes, and these may stimulate these cells through protease-activated receptors. Different quantities of protease enzymes and even differences in other enzymes may stimulate the cells differently via protease-activated receptors or other receptors.

A significant finding was that $D$. farinae and $D$. pteronyssinus extracts induced the secretion of significantly increased levels of CTACK, presumably from keratinocytes. CTACK from keratinocytes plays an important role in attracting subpopulations of memory lymphocytes to the skin [28]. It is interesting that E. maynei extract did not significantly upregulate secretion of CTACK. It is also noteworthy that all 3 mite extracts induced the secretion of the proinflammatory cytokine IL- $1 \alpha$ by HSEs, but the levels induced by D. pteronyssinus and $E$. maynei were significantly increased and were 4-8 times the levels elicited by $D$. farinae extract. We did not see any secretion of IL-1 $\alpha$ by monocultured fibroblasts. However, based on the HSE data, it appears that mite material of some species can induce the synthesis and release of IL$1 \alpha$, probably from keratinocytes, which can contribute to skin inflammation. It is interesting that HSEs released significantly increased levels of IL-1ra in response to only $D$. pteronyssinus and not D. farinae or E. maynei. IL-1ra is a competitive inhibitor of IL-1 by blocking the IL-1 receptor and thus has anti-inflammatory activity. However, in response to the burrowing of the related scabies mite, Sarcoptes scabiei, on their surface, HSEs increased the release of IL-1ra [23]. This could be a response to salivary secretions, fecal material or physical activity from these parasitic mites. This may be an adaptation that the parasite uses to depress the host's inflammatory response and that allows the parasite to reproduce and become established in the host's skin.

An interesting finding of this study was that, in many cases, D. pteronyssinus and E. maynei extracts induced much greater cytokine secretion than did $D$. farinae. The significance of this is not clear and requires further investigation. However, the data suggest that $D$. pteronyssinus and E. maynei may be capable of causing more severe inflammatory reactions in the skin than $D$. farinae.

Our studies with the HSE model have allowed us to investigate cell and matrix interactions that more closely resemble tissue in vivo. The different responses by pure cultured cells and skin equivalent tissue illustrate the danger of using cultured cells to determine the overall effect of dust mites on cells that are involved in allergic and asthmatic reactions. Many studies have stimulated lung epithelial cells in culture with house dust mite extract or recombinant house dust mite allergen [19, 29-35]. These cells produce many cytokines in response to dust mite molecules. These studies have shown that molecules in house dust mite extracts or specific allergens stimulate lung epithelial cells to secrete cytokines, including IL-6, IL-8, GM-CSF and eotaxin (CCL11) [29-37]. These same cytokines and chemokines are released by cultured fibroblasts and keratinocytes and by the cells in HSEs. It is not known if these lung/bronchial cells give similar responses in vivo when they interact via cytokines and contact with other cells and a matrix. Given that we have demonstrated that isolated cells behave differently and give different responses than cells in a tissue, this must be considered in the interpretation of these data and the role of these cytokines in airway inflammation and asthma.

It is not clear if the house dust mite extracts used in the present study induced the release of stored cytokines and chemokines from keratinocytes and fibroblasts or if they actually induced the expression of mRNA for the synthesis of these proteins and then their release. Additional study is needed to determine this. 


\section{Conclusion}

Our results using HSEs along with our previous results using monocultured cells show that molecules from house dust mites are capable of inducing the release of multiple proinflammatory cytokines and chemokines from epidermal keratinocytes and dermal fibroblasts. Secretion of cytokines and chemokines by keratinocytes and fibroblasts can play a major role in the pathogenesis of the skin, including atopic dermatitis. The responses we observed in these skin cells were innate responses, because the HSEs contained no immune effector cells such as lymphocytes, mast cells or Langerhans cells. However, chemokines and cytokines from keratinocytes and fibroblasts play a role in the events that lead to the activation and infiltration of inflammatory and immune cells into the skin. House dust mites can induce skin keratinocytes and fibroblasts to secrete cytokines that promote inflammation, and this may contribute to atopic dermatitis and other skin diseases. Avoiding skin contact with house dust mite material would eliminate this possibility. Frequent vacuuming of couches, furniture and carpets and frequent laundering of sheets and other bedding and clothing to remove mite molecules, including allergens, would help reduce the possibility of skin contact.

\section{Acknowledgement}

This work was supported by a grant to L.G.A. from the National Institutes of Health, National Institute of Allergy and Infectious Diseases (NIAID grant AI-017252).

\section{References}

1 Naspitz CK, Diniz C, Candida Rizzo M, Fernandez-Caldas E, Sole D: Human scalps as a reservoir of domestic mites. Lancet 1997; 349:404.

-2 Riley G, Siebers R, Rains N, Crane J, Fitzharris P: House-dust mite antigen on skin and sheets. Lancet 1998;351:649-650.

$\checkmark 3$ Neal JS, Arlian LG, Morgan MS: Relationship among house-dust mites, Der 1, Fel d 1, and Can $\mathrm{f} 1$ on clothing and automobile seats with respect to densities in houses. Ann Allergy Asthma Immunol 2002;88:410-415.

4 Yasueda H, Saito A, Nishioka K, Kutsuwada K, Akiyama K: Measurement of Dermatophagoides mite allergens on bedding and human skin surfaces. Clin Exp Allergy 2003; 33:1654-1658.

5 Leung DY: Atopic dermatitis: new insights and opportunities for therapeutic intervention. J Allergy Clin Immunol 2000;105:860876.

6 Cork MJ, Robinson D, Vasilopoulos Y, Ferguson A, Moustafa M, MacGowan A, Ward SJ, Tazi-Ahnini R: Predisposition to sensitive skin and atopic eczema. Community Pract 2005;78:440-442.

7 Cork MJ, Robinson DA, Vasilopoulos Y, Ferguson A, Moustafa M, MacGowan A, Duff GW, Ward SJ, Tazi-Ahnini R: New perspectives on epidermal barrier dysfunction in atopic dermatitis: gene-environment interactions. J Allergy Clin Immunol 2006;118: $3-21$, quiz 22-23.

-8 Homey B, Steinhoff M, Ruzicka T, Leung DY: Cytokines and chemokines orchestrate atopic skin inflammation. J Allergy Clin Immunol 2006;118:178-189. $\checkmark 9$ Huss-Marp J, Eberlein-Konig B, Breuer K, Mair S, Ansel A, Darsow U, Krämer U, Mayer E, Ring J, Behrendt $\mathrm{H}$ : Influence of shortterm exposure to airborne Der p 1 and volatile organic compounds on skin barrier function and dermal blood flow in patients with atopic eczema and healthy individuals. Clin Exp Allergy 2006;36:338-345.

10 Leung DY: New insights into the complex gene-environment interactions evolving into atopic dermatitis. J Allergy Clin Immunol 2006;118:37-39.

11 Thomas WR, Smith WA, Hales BJ, Mills KL O'Brien RM: Characterization and immunobiology of house dust mite allergens. Int Arch Allergy Immunol 2002;129:1-18.

12 Maas-Szabowski N, Shimotoyodome A Fusenig NE: Keratinocyte growth regulation in fibroblast cocultures via a double paracrine mechanism. J Cell Sci 1999;112:18431853.

13 Nakamura T, Hirasawa Y, Takai T, Mitsuishi K, Okuda M, Kato T, Okumura K, Ikeda S, Ogawa H: Reduction of skin barrier function by proteolytic activity of a recombinant house dust mite major allergen Der f 1. J Invest Dermatol 2006;126:2719-2723.

14 Ring J, Darsow U, Behrendt H: Role of aeroallergens in atopic eczema: proof of concept with the atopy patch test. J Am Acad Dermatol 2001;45:S49-S52.
15 Darsow U, Laifaoui J, Kerschenlohr K, Wollenberg A, Przybilla B, Wüthrich B, Borelli S Jr, Giusti F, Seidenari S, Drzimalla K, Simon D, Disch R, Borelli S, Devillers AC, Oranje AP, De Raeve L, Hachem JP, Dangoisse C, Blondeel A, Song M, Breuer K, Wulf A, Werfel T, Roul S, Taieb A, Bolhaar S, BruijnzeelKoomen C, Brönnimann M, Braathen LR, Didierlaurent A, André C, Ring J: The prevalence of positive reactions in the atopy patch test with aeroallergens and food allergens in subjects with atopic eczema: a European multicenter study. Allergy 2004;59:13181325 .

-16 Fuiano N, Incorvaia C, Prodam F, Procaccini DA, Bona G: Relationship between the atopy patch test and clinical expression of the disease in children with atopic eczema/dermatitis syndrome and respiratory symptoms. Ann Allergy Asthma Immunol 2008; 101:174-178.

17 Wan H, Winton HL, Soeller C, Tovey ER, Gruenert DC, Thompson PJ, Stewart GA, Taylor GW, Garrod DR, Cannell MB, Robinson C: Der p 1 facilitates transepithelial allergen delivery by disruption of tight junctions. J Clin Invest 1999;104:123-133.

18 Wan H, Winton HL, Soeller C, Taylor GW, Gruenert DC, Thompson PJ, Cannell MB, Stewart GA, Garrod DR, Robinson C: The transmembrane protein occludin of epithelial tight junctions is a functional target for serine peptidases from faecal pellets of Dermatophagoides pteronyssinus. Clin Exp Allergy 2001;31:279-294.

19 Capetandes A, Horne NS, Frieri M: Dermatophagoides extract-treated confluent type II epithelial cells (cA549) and human lung mesenchymal cell growth. Ann Allergy Asthma Immunol 2005;95:381-388. 
-20 Arlian LG, Morgan MS, Peterson KT: House dust and storage mite extracts influence skin keratinocyte and fibroblast function. Int Arch Allergy Immunol 2008; 145:33-42.

-21 Arlian LG, Elder BL, Morgan MS: House dust mite extracts activate cultured human dermal endothelial cells to express adhesion molecules and secrete cytokines. J Med Entomol 2009;46:595-604.

-22 Kato T, Takai T, Fujimura T, Matsuoka H, Ogawa T, Murayama K, Ishii A, Ikeda S, Okumura K, Ogawa H: Mite serine protease activates protease-activated receptor- 2 and induces cytokine release in human keratinocytes. Allergy 2009;64:1366-1374.

23 Morgan MS, Arlian LG: Response of human skin equivalents to Sarcoptes scabiei. J Med Entomol 2010;47:877-883.

-24 Arlian LG, Vyszenski-Moher DL, Rapp CM, Hull BE: Production of IL-1 alpha and IL-1 beta by human skin equivalents parasitized by Sarcoptes scabiei. J Parasitol 1996;82:719723.

-25 Bradford MM: A rapid and sensitive method for the quantitation of microgram quantities of protein utilizing the principle of proteindye binding. Anal Biochem 1976;72:248254.

26 Tan BB, Weald D, Strickland I, Friedmann PS: Double-blind controlled trial of effect of housedust-mite allergen avoidance on atopic dermatitis. Lancet 1996;347:15-18.
27 Trivedi B, Valerio C, Slater JE: Endotoxin content of standardized allergen vaccines. Allergy Clin Immunol 2003;111:777-783.

-28 Morales J, Homey B, Vicari AP, Hudak S, Oldham E, Hedrick J, Orozco R, Copeland NG, Jenkins NA, McEvoy LM, Zlotnik A: CTACK, a skin-associated chemokine that preferentially attracts skin-homing memory T cells. Proc Natl Acad Sci USA 1999;96: 14470-14475.

29 King C, Brennan S, Thompson PJ, Stewart GA: Dust mite proteolytic allergens induce cytokine release from cultured airway epithelium. J Immunol 1998;161:3645-3651.

30 Tomee JF, van Weissenbruch R, de Monchy JG, Kauffman HF: Interactions between inhalant allergen extracts and airway epithelial cells: effect on cytokine production and cell detachment. J Allergy Clin Immunol 1998;102:75-85

-31 Sun G, Stacey MA, Schmidt M, Mori L, Mattoli S: Interaction of mite allergens Der p3 and Der p9 with protease-activated receptor-2 expressed by lung epithelial cells. J Immunol 2001;167:1014-1021.

32 Asokananthan N, Graham PT, Stewart DJ, Bakker AJ, Eidne KA, Thompson PJ, Stewart GA: House dust mite allergens induce proinflammatory cytokines from respiratory epithelial cells: the cysteine protease allergen, Der $\mathrm{p}$ 1, activates protease-activated receptor (PAR)-2 and inactivates PAR-1. J Immunol 2002;169:4572-4578.
33 Kuderer NM, San-Juan-Vergara HG, Kong X, Esch R, Lockey RF, Mohapatra SS: Mite and cockroach proteases activate p44/p42 MAP kinases in human lung epithelial cells. Clin Mol Allergy 2003;1:1.

-34 Kauffman HF, Tamm M, Timmerman JA, Borger P: House dust mite major allergens Der p 1 and Der p 5 activate human airway-derived epithelial cells by protease-dependent and protease-independent mechanisms. Clin Mol Allergy 2006;4:5.

35 Wong CK, Li ML, Wang CB, Ip WK, Tian YP, Lam CW: House dust mite allergen Der p 1 elevates the release of inflammatory cytokines and expression of adhesion molecules in co-culture of human eosinophils and bronchial epithelial cells. Int Immunol 2006; 18:1327-1335.

$>36$ Reed CE, Kita H: The role of protease activation of inflammation in allergic respiratory diseases. J Allergy Clin Immunol 2004;114: 997-1008.

37 Adam E, Hansen KK, Astudillo Fernandez O, Coulon L, Bex F, Duhant X, Jaumotte E, Hollenberg MD, Jacquet A: The house dust mite allergen Der p 1, unlike Der p 3, stimulates the expression of interleukin- 8 in human airway epithelial cells via a proteinaseactivated receptor-2-independent mechanism. J Biol Chem 2006;281:6910-6923. 